\title{
ANNUAL GENERAL IIETING.
}

Fridat, 8rit Febroart, 1901.

W. T. Brasford, LL.D., F.R.S., etc., President, in the Chair.

The minutes of the prerious Annual General Meeting haring been read, the President addressed those present as follows :-

"Before proceeding to the business of the annual meeting, I feel sure that it will be the wish of all present and of all members of our Society that I should express our profound sorrow at the loss which the Empire has sustained in the death of our beloved Sorereign, Her Most Gracious Majesty Queen Victoria. During her long and glorious reign, seren-cighths of which had passed before the Malacological society came into existence, erery science has flourished in our land, and even the branch of Natural IIistory to which we are deroted has undergone a complete and beneficial transformation through the progress of studies in anatomy, physiology, and erolution. The memory of the great Queen whom we have lost, of all her kindly and gracious acts, of her love for her people, and of the profound attention and reverence with which they regarded her, will live in the hearts of many a generation of our countrymen, and it may be hoped.will inspire them with that lore of honesty and truth by which she was pre-eminently distinguished, and which is the foundation of all scientific enquiry. Ferr as are the members of our Society, and small as may be the share we take amongst the rast scientific enterprise of the cirilized world, we cannot allow the Queen's decease to pass unnoticed, nor can we omit to join in the universal expression of grief at the nation's loss, or in the equally unirersal feeling of sympathy with her late MIajesty's son and successor, King Edrard VII, who we hope will long occupy the throne of his ancestors in peace and prosperity."

Mr. H. Fulton and MTr. TV. M. Webb were appointed scrutineers.

The following report was read :-

"Your Council, in presenting their eighth Annual Report, hare once more to record a jear of steady progress.

During the past year four members have resigned; while the Society has further to deplore the loss of two of its members by death.' Six

' Dr. C. C. Claremont and Mr. G. Sherriff Tye, both original members. 
members have been removed from the Society's list in accordance with Rule X. The Societs has thus lost twelve members, while four new members only have been clected; two candidates awaited election at the close of the year.

The membership of the Society on December 31 st stood as follows :-

$$
\begin{array}{lrrrrrr}
\text { Ordinary members f.... } & \ldots . . . & \ldots . . & \ldots . . & \ldots . . & \ldots . & 90 \\
\text { Corresponding members } & \ldots . . & \ldots . . & \ldots . . & \ldots . . & \ldots . & 78 \\
& & & & & & \\
& & & & & & \\
& & & & &
\end{array}
$$

the totals for the two preceding sears being 176 in 1899, and 168 in 1898 .

The finances of the Socicty are in a flourishing condition. After the pajment of all liabilities there is a balance of $£ 37148$. $6 \mathrm{~d}$. in the 'I'reasurer's hands, whilst the sum of $£ 50$ 'still remains invested in Metropolitan $2 \frac{1}{2}$ per cent. Stock.

I'wenty-four communications have been made to the Society by fifteen authors.

Since the last Annual General Mreeting three more numbers of the 'Proceedings' have been issued, forming the first half of Vol. IV, comprising 150 pages, with thirteen plates and numerous illustrations in the text.

Your thanks are due to the following gentlemen, who have borne a proportion of the cost of illustration or who have assisted by furnishing drawings: W. E. Collinge, S. I. Da Costa, Miss J. Donald, Lieut.-Col. H. H. Godrin-Austen, G. K. Gude, J. C. Melvill, R. Murdoch, H. A. Pilsbry, W. B. Randles, E. A. Snith, G. 13. Sowerby, E. R. Sykes, and II. F. Woodward.

Further, your thanks are specially due to the Council of tho Linnean Society, through whose kindness this Society has been permitted, as in previous years, to hold its meetings in Burlington House."

On the motion of Professor Dr. G. B. Howes, scconded by Mr. R. H. Burne, the foregoing was adopted as the Annual Report of the Socicty.

The following were elected as Officers and Council for the year 1901 :

President.-E. A. Smith, F.Z.S.

Fice-Presidents.-W. T. Blanford, LL.D., F.R.S. ; Licut.-Col. H. H. Godwin-Austen, F.R.S.; Rer. Canon Merle Norman, D.C.L., F.R.S.; E. R. Sykes, B.A., F.L.S.

Treasurer.-J. H. P'onsonby, H.Z.S.

Secretary.-II. F. Woodwarl.

Editor.-B. B. Woodward, F.L.S.

Six other Members of the Council.-Rer. R. Ashington Bullen, F.L.S.; R. H. Burne, B.A., F.Z.S.; G. C. Crick, F.G.S.; G. K. Gude, F.Z.S. ; W. F. Hoyle, II.A., M.R.C.S.; H. Woodward, LL.D., F.R.S.

The retiring I'resident, Dr. Blanford, gave a short address, in which he commented upon the present satisfactory condition of the Societ5, and gave a brief reriew of the work done during his term of office. 
He regretted that he was unable to give the Society a formal address, and concluded with some interesting remarks upon the geographical distribution of the land mollusca in different parts of the world, a subject which he thought might well occupy the attention of malacologists. He specially pointed out that the systems of division of the earth's surface into zoological areas at present in rogue, notably Sclater's, could not be applied to the land mollusca, citing amongst other cases that of Australia, where the northern land mollusca were absolutely distinct from those of the south and indicated a different origin.

On the motion of Mr. S. I. Da Costa, seconded by Mr. H. B. Preston, a rote of thanks was passed to the Retiring Officers, the Retiring Members of Council, the Auditors, and the Scrutinecrs, Dr. Blanford, the Retiring President, being specially thanked for his valuable services.

\section{ORDINARY MEETING.}

Friday, 8th Febroary, 1901.

E. A. Smitn, F.Z.S., President, in the Chair.

Richard II. Bentley was elected to membership of the Societs.

Exhibitions were placed on the table by the following :-

Mr. J. E. S. Moore: a large series of mollusca collected by him during his second risit to Lakes Tanganyika and Nyassa and the Great African Lakes forming the sources of the Nile. He drew special attention to the fact that no traces could be found in Nyassa, Kivu, Albert Edward, Albert, and Victoria Nyanzas of the strange fauna which is so characteristic of Tanganyika. Amongst the exhibits was a supposed new species of Bythoceras from Tanganyika, and a new Gastropod from Albert Edward Nyanza. This shell resembles a Planorbis in form, but appears to be in reality a Alelania.

Mr. E. A. Smith: a small box of the so-called Breeding Pearls, presented to him by Mr. H. M. Bernard.

Mr. E. R. Sykes: some rare Volutes ( $V$. Sophia), and a large series of Achatinclla from the Philippines illustrating their extraordinary variation.

Mr. J. E. Cooper : a series of distorted British Lamellibranchs, also the rare Myrina Simpsoni, Marshall, from Fisher Bank, east of Orkneys, and Ilangilia rugosa, l'hil., from Achil Island, co. Mayo.

Mr. S. I. Da Costa : a collection of Aperostoma from South and Central America.

The Rev. R. Ashington Bullen : a large series of Cyprac, showing colour variations; also a series of Helices. 